\title{
Assessment of Rice Market Competiveness Using Horizontal Price Transmission: Empirical Evidence from Southern Region of Nigeria
}

\author{
S. B. Akpan, S. J. Udoka,V. P. Inimfon
}

Department of Agricultural Economics and Extension, Akwa Ibom State University, Nigeria

\begin{abstract}
The study examined the horizontal price transmission and market integration between the local and foreign rice market in the Southern region of Nigeria. The study used average monthly prices of local and foreign rice in the rural and urban markets from January 2005 to June 2014. The findings show that, prices of local and foreign rice in the rural and urban markets have constant exponential growth rate of $0.60 \%$. The Pearson correlation coefficient revealed a strong positive relationship between prices of local and foreign rice in both rural and urban markets. The cross-product Granger causality test revealed bidirectional relationship between prices of local and foreign rice in the region. The results of the cross co-integration test revealed the presence of co-integration between prices of the two products. The coefficients of the price variable in the cross co-integration equations for the local and foreign rice markets converge to the law of one price which connotes instantaneous price adjustment and competitiveness. The result of the cross - product error correction model also confirmed the existence of the short run market integration between the two markets. The study established the fact that, price of local rice competes favorably with its foreign counter part and thus a perfect substitute especially in the rural area. Based on the finding, it is recommended that, short term policies should be used to intervene in the rice sub sector in the region. Policies aimed at boosting local production of rice should be encouraged, while value additions in the domestic produced rice should be pursuit vigorously.
\end{abstract}

\section{Keywords}

Market, rice, integration, agricultural, Akwa Ibom, Nigeria.

JEL Classification: Q13

Akpan, S. B., Udoka, S. J. and Inimfon, P. V. (2016) "Assessment of Rice Market Competiveness Using Horizontal Price Transmission: Empirical Evidence from Southern Region of Nigeria", AGRIS on-line Papers in Economics and Informatics, Vol. 8, No. 1, pp. 3-18. ISSN 1804-1930, DOI 10.7160/aol.2016.080201.

\section{Introduction}

Rice is one of the most important staple foods in Nigeria. Among Nigerian, rice is a normal good, hence has positive income elasticity (Udoh et al., 2013). The country is an important producer of rice in West Africa (Daramola, 2005). The West African sub-region accounted for about $56 \%$ of the total production in Africa, and Nigeria produces about $23 \%$ of the quantity (Kehinde, 1999; Daramola, 2005). The production of rice is done basically by smallholder farmers who have limited farm resources, poor technology, and produce an average of 4.6 tons of paddy per year from an average crop area of 3.30 hectares (Erenstein et al., 2004; Daramola, 2005). Following the works of Akpokodje et al., (2001), Daramola (2005) a Imolehin and Wada (2000), rice is cultivated in five production systems in Nigeria, namely: rain-fed upland (30\%),rain-fed lowland $(47 \%)$, irrigated lowland $(17 \%)$, deep water $(5 \%)$ and mangrove swamp (1\%). The level of domestic rice production in Nigeria is about 3.5 million metric tons per annum; while the domestic demand stood at about 6.1 million metric tons per annum (CBN, 2014 and USA, department of Agriculture, 2014). This shortfall in supply creates incentive for rice importation in the country as noted by Daramola (2005) and Awe (2006). Total import oscillates from 1.7 million tons to 3.2 million tons, depending on the demand strength, tariff structure, macroeconomic variability, and annual domestic production among others. Following this shortfall 
in supply, the country spends about $\$ 4 \mathrm{~b}$ per year for the importation of processed rice (CBN, 2014). This has huge implications on the country's' foreign reserve and the development of domestic rice sub sector.

Owing to the important of rice sector to the citizenry and the national economy, the federal government has implemented several policies to boost rice production in the country. Government has set up several tariff regimes, imposed banned on importation of rice, implemented import restriction license, quantitative restrictions, and abolished Commodity Boards among others. The Presidential Initiative on Rice was also inaugurated in 2002 with several aims including improved household food security and income, reduction in rural poverty, increase in domestic rice production such that supply will exceed demand and surpluses exported among others. Other institutional based policy includes; Nigerian National Rice Development Strategy (NNRDS) form in 2009. The agency was saddled with the responsibility of adding value to locally produced rice among others. Despite these incentives, the country domestic rice sector is still wallowed in low productivity, sluggish competition with foreign counterpart in terms of supply, quality (value addition) and consumer preference (demand). The resultant effect has been the relegation of the domestic rice sub sector and soaring of foreign rice imports in recent years.

The magnitude of foreign rice in the country's domestic market has a serious effect on the local production, competitiveness and the development of subsidiary rice markets. Unguided international trade policies can lead to dumping, diversification and neglect of vital sectors of the economy. It appears that, not much information are available in the country to analyze the interdepency between local and foreign rice markets. This could lead to mis-specification of policies. To avoid this situation, agricultural economist have devise ways to assess the degree of interaction and interdependency among tradable commodities in different markets. Price trend analysis, price transmission study and market integration study are among methodologies often used to assess the efficiency of commodity market interaction among, between and within markets (Listorti and Esposti, 2012). The study of price transmission has been motivated largely by the view that co-movement of prices in different markets can be interpreted as a sign of efficient markets, while the absence of price co-movement can be viewed as a sign of market failure (Ghoshray, 2011). Commodity prices and consumer food prices depends on horizontal and vertical price transmission (Ferrucci et al., 2012; Lloyd et al., 2012).

On the other hand, spatial market integration shows the efficiency of the market and also indicates the proficiency of marketing infrastructures in the region under consideration (Faminow and Benson, 1990). Understanding market integration is important particularly in needs assessments as policy makers need to avoid over-estimating or under-estimating the ability of markets to respond to price or any exogenous shock. Market integration helps in the optimization of resource use; increase in farm incomes; widening of markets; promote growth of agrobased industries, encourage value addition and also create employment (Acquah and Owusu, 2012). The analysis of spatial market integration thus, provides indication of competitiveness, effectiveness of market arbitrage, and the efficiency of pricing (Sexton, Kling and Carman 1991). This often associated with symmetric price integration.

This study employed these methodologies to assess the level of competitiveness between the local and foreign rice market in the southern region of Nigeria. The horizontal price transmission analysis was used because the two rice markets are distinct or differentiated (Esposti and Listorti, 2012). In an attempt to achieve this objective, the following specific objectives were pursuit:

1) To examine the trends and price differential in the local and foreign rice market in the region,

2) To determine the efficiency of horizontal information flow or horizontal price transmission between the local and foreign rice market, and

3) Access the extent of cross market integration and speed of price adjustment between the local and foreign rice markets in the region.

\section{Review of relevant literature}

Several authors have applied the Law of One Price to study price transmission in agricultural commodities. Noticeably among them are: Ravallion (1986), Goletti and Babu (1994), Baffes and Ajwad (2001) and Barrett (2001) as well as Esfahani (2006). However, most of the results were controversial, and sensitive to the techniques employed. Also, co-integration, error correction model and Granger causality test have been used 
to study agricultural price transmission. Some of the recent empirical evidences are included in the following: Acquah and Owusu (2012) in Ghana; Zahid et al. (2007) and Hussain (2010) in Pakistan, Gonz alez-Rivera and Helfand (2001) in Brazil rice sector; Dawson and Dey (2002) and Hossain and Verbeke (2010) in Bangladesh rice sector; Bakucs et al. (2007) in Hungary tomato sub sector and Worako et al. (2008) in Ethopia coffee industry.

Enders and Silkos (1999) introduced threshold model to ascertain the asymmetric nature in price transmission in agricultural commodities. Abdulai (2002) and Sephton (2003) have employed this methodology to assess price transmission in agricultural commodities. This type of model is aimed at testing for the presence of non- linear transaction costs, and in general for the existence of price bands within which there is no transmission. Recently, Rezitis and Dimitris (2013) used Markov Switching vector error correction model to investigate price transmission mechanism of fresh tomato market in Greek. The results indicated that there were causality and leadership relationships between producer and consumer prices in the short and long runs. In a similar way, Hassan and Simmioni (2001) found that causality runs from producer to retailer in French tomato market. Moreover, Goodwin and Harper (2000) in US discovered that pork market price transmission shocks in the marketing channel are unidirectional and that information flows from producer to consumer. On the other hand, Ben-Kaabia and Gil (2007) explored the Spanish lamp market and observed that retailers benefit from shocks that affect the marketing channels for lamps. Vavra and Goodwin (2005), using a TVEC model, examined the price transmission mechanism of beef, chicken and eggs in the US. Jezghani et al. (2013) used vector error correction model (VECM) to investigate the spatial market integration in Iranian rice market. The result revealed significant market integration between Iran and Thailand rice market, with Thailand market been the lead market. Chirwa (2000) studied the food marketing reforms and integration of maize and rice markets in Malawi. He discovered that the rice market was more integrated than maize market. Suryaningrum et al. (2013) investigated the spatial market integration of Thailand and Vietnam rice market in Indonesia by using real price monthly data. Johanson co-integration test approach was employed to examine the long-run price relationship, while the short-term relationship was examined by vector error correction model (VECM). The results showed that, the long-run relationships existed among Thailand, Vietnam, and Indonesian rice markets. Furthermore, Dawson and Dey (2012) studied the spatial market integration among major domestic rice markets in Bangladesh. An integrated empirical framework tested long-run spatial market integration between price pairs using a dynamic vector autoregressive model and co integration. Hypotheses tests of market integration, perfect market integration, and causality were conducted sequentially using monthly prices from rice markets in Bangladesh since trade liberalization in 1992. The results showed that rice markets in Bangladesh were perfectly integrated.

In Nigeria few literature exist on agricultural price transmission. Methodologies ranging from descriptive, LOP, causality tests, co-integration and ECM are popular among Nigerian authors. For instance, in Nigeria, Okoh and Egbon (2005) examined the integration of Nigeria's rural and urban foodstuffs markets. The study concluded that, the rural and urban foodstuffs markets were well integrated. The results further suggested that the urban market price drives the rural market price. Akintunde et al. (2012) studied the long run price integration of grains in Oyo state, western Nigeria. The integration test showed that none of the markets examined had prices tied together in the long- run. Also, Debaniyu, (2012) investigated grain (cowpea) market integration in northern Nigeria. He employed time series methodology and discovered that some markets in the study area were integrated in the long run. Akpan et al. (2014) examined the price transmission and market integration in local and foreign rice in the rural and urban markets in Southern region of Nigeria. The findings show that, prices of local and foreign rice in rural and urban markets has a constant exponential growth rate of $0.59 \%$. Also, the Pearson correlation coefficient matrix revealed that, the rural price of local and foreign rice has significant positive linear relationships with their corresponding urban prices. The Granger causality test revealed bidirectional relationship between rural and urban price of local and foreign rice in Akwa Ibom State, Nigeria. The results of the co-integration test revealed the presence of co-integration between the rural and urban prices of local and foreign rice as well as support the hypothesis of perfect price transmission between the two markets in the study area. The results of the error correction model also confirm 
the existence of the short run market integration between the rural and urban prices of local and foreign rice in the study area.

Premised on the imbalance in the rice market in most developing countries like Nigeria, the myriad of literature available on price transmission and market integration have not delved into the relationship between the local (rice produced in Nigeria) and foreign rice (rice produced outside Nigeria) market in the domestic economy. This relationship is imperative due to the increasing dominant of foreign rice import in most developing economies. Hence, this research was specifically designed to provide empirical fact needed to understand and address this issue appropriately.

\section{Materials and methods}

\section{Study area}

The study was conducted in one of the states (Akwa Ibom State) in the South-South region of Nigeria. The state was picked because it is central and represents one of the viable economic centers in the region. It has a distinct rural and urban settlement and is not prone to violence as compared to other states in the region. The region is popularly called the Niger Delta region or the oil rich region of Nigeria. The state is located between latitudes $4^{\circ} 321$ and $5^{\circ} 331$ north and longitudes $7^{\circ} 251$ and $8^{\circ} 251$ east. It has a total land area of areas of $7,246 \mathrm{~km}^{2}$. The mean annual temperature of the state lies between $26^{\circ} \mathrm{C}$ and $29^{\circ} \mathrm{C}$ and average sunshine of about 1,450 hours per year. The mean annual rainfall ranges from $2,000 \mathrm{~mm}$ to $3,000 \mathrm{~mm}$, depending on the area. Akwa Ibom State has a population of over 3,902,051 (National Population Commission, 2006). The state is basically an agrarian society where crops like maize, okra, cassava, yam and rice are cultivated in large quantities.

\section{Source of data}

Average monthly retailed prices (measured in Naira per kilogram) of foreign and local rice in rural and urban markets were used in this study. The data came from the quarterly publication of the Akwa Ibom State Agricultural Development Programme (AKADEP). The study period covered January 2005 to June 2014. A total of 114 average monthly prices $(\mathrm{N} / \mathrm{Kg})$ of local and imported rice from rural and urban markets were used in the study.

\section{Analytical techniques}

The study applied trend analysis, bi-variate correlation analysis and t-test, Granger causality tests, co-integration and Error Correction Model (ECM) to evaluate its objectives. Each of the tests is explained in both explicit and implicit below:

The trend tnalysis of average monthly retailed prices of local and foreign rice in rural and urban markets in Akwa Ibom State in Nigeria

The nature of growth rate in prices of local and foreign rice in both rural and urban market was investigated by employing the exponential price equation as specified below:

$P_{t}=b_{o} e^{b t} e^{u t}$

$\log _{e} P_{t}=\log _{e} b_{0}+b_{1} t+U_{t}$

Where exponential growth rate $(\mathrm{r})=\left(e^{b 1}-1\right)^{*} 100$.

" $P_{t}$ " is represented by:

$L_{r t}=$ Average monthly price of local rice in rural market in Naira/Kg

$F_{u t}=$ Average monthly price of foreign rice in Urban market in Naira/Kg

$L_{u t}=$ Average monthly price of local rice in urban market in Naira/Kg

$F_{r t}=$ Average monthly price of foreign rice in rural market in Naira/Kg

$\mathrm{t}=$ time trend $(1,2, \ldots, 114)$

The exponential price equation was used because, several literature have supported consistence rise in prices of agricultural commodities for some years past in Nigeria (Akpan, 2009, Famine Early Warning Systems Network (FEWSNET) 2008, Odozi and Bolarin 2012). Hence, it was assumed that, changes in prices of local and foreign rice in Akwa Ibom State should be investigated using non-linear model.

Bilateral Granger Causality Test between Prices of local and Foreign Rice in Akwa Ibom State, Nigeria

A long run cross product Granger causality model was used to test the relationship between price movement in local and foreign rice in Akwa Ibom State. The number of lags used in the estimation was determined by Akaike and Schwarz information criteria. The primary model in Vector Autoregressive Regression forms are represented as thus: 


$$
\begin{aligned}
& \left\{\begin{array}{l}
\Delta L n L_{r t}=\beta_{0}+\beta_{1} \sum_{i=1}^{n} \Delta L n L_{r t-1}+\beta_{2} \sum_{i=1}^{n} \Delta L n F_{u t-1}+\varepsilon_{1 t}(3) \\
\Delta L n F_{u t}=\delta_{0}+\delta_{1} \sum_{i=1}^{n} \Delta L n F_{u t-1}+\delta_{2} \sum_{i=1}^{n} \Delta L n L_{r t-1}+\varepsilon_{2 t}(4)
\end{array}\right\} \\
& \left\{\begin{array}{l}
\Delta \boldsymbol{L} \boldsymbol{n} L_{u t}=\gamma_{0}+\gamma_{1} \sum_{i=1}^{n} \boldsymbol{L n} L_{u t-1}+\gamma_{2} \sum_{i=1}^{n} \Delta L n F_{r t-1}+\varepsilon_{3 t} \\
\Delta \boldsymbol{L} \boldsymbol{n} F_{r t}=\alpha_{0}+\alpha_{1} \sum_{i=1}^{n} \Delta \boldsymbol{L} n F_{r t-1}+\alpha_{2} \sum_{i=1}^{n} \Delta L n L_{u t-1}+\varepsilon_{4 t} \quad(6)
\end{array}\right\}
\end{aligned}
$$

A unilateral Granger causality implies inefficiency in price movement between foreign and domestic rice sub sectors in the long run. This will also connotes that, both markets are weakly competitive in the region. On the other hand, mutual or bidirectional Granger causality implies smooth or symmetric price movement between the local and foreign rice market in the study area. This connotes strong substitutability and competitiveness of both markets.

\section{Co- integration test on prices of local and foreign} rice in Akwa Ibom State, Nigeria

Co- integration involves the determination of the long-run relationship among non-stationary time series. If two markets are integrated, then there exists an equilibrium long run relationship between these markets (Goodwin and Schroeder, 1991; Gonzalez-Rivera 2001; Sexton, Kling, and Carman, 1991). The study applied the Engle and Granger two-step technique and Johansen co-integration approach to examine the co-integration relationships between local price and foreign price of rice in the study area. The specification is shown in equation 7 and 8 . If two markets are perfectly integrated, then $\gamma_{1}=1$ in equation 7 (law of one price). In this case, price changes in local rice in the rural market are fully reflected in the foreign rice prices in the urban market. When $\gamma_{1} \neq 1\left(\gamma_{1}<1\right.$ or $\left.\gamma_{1}>1\right)$, then the degree of market integration needs to be determined by investigating the variance of $\gamma_{1}$ from the threshold mark of 1 .

$$
\begin{aligned}
& L n L_{r t}=\gamma_{0}+\gamma_{1} \sum_{i=1}^{n} L n F_{u t}+U_{1 t} \\
& L n F_{r t}=\varphi_{0}+\varphi_{1} \sum_{i=1}^{n} \operatorname{Ln} L_{u t}+U_{2 t}
\end{aligned}
$$

Co-integration between the price series analyzed implies that two prices may behave in a different way in the short run, but that they will converge toward a common behaviour in the long run.
If this property is verified, the characteristics of the dynamic relationship between the prices can be described by an Error Correction Model (ECM). Following the work of Barrett and Li (2002), the short-run adjustment parameter of the ECM can be interpreted as a measure of the speed of price transmission, while the long run multiplier can be interpreted as a measure of the degree of price transmission of one price to the other. The properties of co-integrated series also imply the existence of a causality relation, as defined by Granger, that can be tested by assessing if the past observations of one of the two prices (fail to) predict those of the other. Following the Granger Representation Theorem, we specify the Error Correction Model (ECM) for the co-integrating series in the study. The general specification of the ECM that was estimated for the rural price equations for local and foreign rice in the state is shown below:

$$
\begin{aligned}
\Delta \mathrm{LnL}_{r t} & =\gamma_{0}+\gamma_{1} \sum_{i=1}^{n} \Delta L n L_{r t-1}+\gamma_{2} \sum_{i=1}^{n} \Delta \mathrm{LnF}_{u t-i} \\
& +\gamma_{3} \text { ECM }_{t-1}+U_{1 t} \\
\Delta \mathrm{LnF}_{r t} & =\vartheta_{0}+\vartheta_{1} \sum_{i=1}^{n} \Delta L n F_{r t-1}+\vartheta_{2} \sum_{i=1}^{n} \Delta L n L_{u t-i} \\
& +\vartheta_{3} E_{C M} M_{t-1}+U_{2 t}
\end{aligned}
$$

Variables are as defined previously in equation $(2)$, and coefficients $\left(\gamma_{3}\right)$ and $\left(\vartheta_{3}\right)$ lie in the range of $\left(-1<\gamma_{3}, \vartheta_{3}<0\right)$, and measure the deviations from the long-run equilibrium in period $\left(\mathrm{t}_{-1}\right)$ in both $L_{r t}$ and $F_{r t}$. In order to obtain a parsimonious dynamic ECM for the rural price equation, the study adopted Hendry's (1995) approach in which an over parameterized model is initially estimated and then gradually reduced by eliminating insignificant lagged variables until a more interpretable and parsimonious model is obtained.

\section{Results and discussion}

Descriptive analysis of urban and rural monthly prices of local and foreign rice in Akwa Ibom State

The descriptive statistics of price variables used in the analyses is shown in Table 1 . The average prices of local and foreign rice in the rural market stood at $\mathrm{N} 161.19 / \mathrm{kg}$ and $\mathrm{N} 219.77 / \mathrm{kg}$ respectively. In urban market, the mean price was N158.11/kg and $\mathrm{N} 215.14 / \mathrm{kg}$ for local and foreign rice respectively. 


\begin{tabular}{|l|c|c|c|c|}
\hline \multirow{2}{*}{ Parameters } & \multicolumn{2}{|c|}{ Local rice } & \multicolumn{2}{c|}{ Foreign rice } \\
\cline { 2 - 5 } & $\begin{array}{c}\text { Rural market } \\
(\mathrm{N} / \mathrm{Kg})\end{array}$ & $\begin{array}{c}\text { Urban market } \\
(\mathrm{N} / \mathrm{Kg})\end{array}$ & $\begin{array}{c}\text { Rural market } \\
(\mathrm{N} / \mathrm{Kg})\end{array}$ & $\begin{array}{c}\text { Urban market } \\
(\mathrm{N} / \mathrm{Kg})\end{array}$ \\
\hline Mean & 161.19 & 158.11 & 219.77 & 215.14 \\
\hline Median & 166.78 & 163.15 & 233.97 & 226.73 \\
\hline Minimum & 100.42 & 98.75 & 129.63 & 139.17 \\
\hline Maximum & 224 & 232.09 & 308 & 307 \\
\hline Standard deviation & 34.601 & 34.184 & 45.462 & 45.483 \\
\hline Coefficient of Variation & 0.218 & 0.216 & 0.207 & 0.211 \\
\hline Skewness & -0.112 & 0.002 & -0.245 & -0.062 \\
\hline Kurtosis & -1.184 & -1.039 & -1.276 & -1.172 \\
\hline
\end{tabular}

Note: Prices are expressed in nominal terms Source: Own processing

Table 1: Descriptive statistics of rice variables used in the analysis.

The minimum and maximum prices of local rice in the rural markets were N100.42 and N224.00 respectively. Likewise, it was N98.75 and N232.09 repectively in urban market. Prices of foreign rice has larger ranges in both rural and urban markets compared to local rice. This shows evidence of price variations between the rural and urban markets for local and foreign rice in the study area. The standard deviations in prices of local and foreign rice rotate around 34 and 45 respectively. Similarly, the coefficient of variability in price variables fluctuate approximately around $22 \%$ and $21 \%$ for local and foreign rice market respectively. This implies that, change in prices of local and foreign rice in both markets assumes relatively the same magnitude.

Exponential trend analysis of prices of local and foreign rice in rural and urban markets in Akwa Ibom State

The exponential trend equation for each of the price variables specified in equations 2 is presented in Table 2. The result also contains the estimated exponential growth rate for each of the price variables and the nature of such growth rate over time. The result revealed that, prices of local and foreign rice in the rural and urban markets showed positive significant relationship with time. This implies that, fluctuation in prices of local and foreign rice in both markets is influenced by time. A stationary exponential growth rate of about $0.60 \%$ for all price variables was discovered in both markets. This result suggests that, variance and growth rate in prices of local and foreign rice in rural and urban markets are relatively stable over time. The nature of growth in each price variable showed that, over increase time the price of foreign rice in rural and urban markets exhibited significant marginal declined in the state. However, the marginal declined was insignificant in the local rice market.

Graphically, price trend in the local and foreign rice in both rural and urban markets was compared by using plotted linear trend diagrams and is presented in figure 1 and 2. Trend in prices of local rice in the rural market and foreign rice in the urban market is shown in figure 1. The result shows significant dispersion between the two prices. Both price trended upward significantly showing strong correlation, but the price of foreign rice exhibited higher trend, suggesting that, price difference in both products is conspicuous and relatively similar during the study period.

In the similar manner, figure 2, shows the linear trend in prices of local rice in the urban market and foreign rice in the rural markets. The result is similar to what is obtained in figure 1. To compare the nature of price fluctuation in both products in rural and urban market, it is obvious that, price gap existed between them, but both showed strong correlation in pattern of fluctuation. This result again pointed to the fact that, there is market competition between the local and foreign rice market in Southern region of Nigeria. One of the possible reasons for this result could be that, the foreign rice is a good substitute of the local rice probably due to consumers' preference, quality, and availability among others.

Further descriptive techniques were employed to analyze price movement in both products. Since both variables are similar and measured in the same unit, the paired t-test and Pearson 


\begin{tabular}{|c|c|c|c|c|}
\hline Variables & $\operatorname{LnL}_{r t}$ & $\boldsymbol{L n} \boldsymbol{L}_{u t}$ & $\operatorname{LnF}_{r t}$ & $L n F_{u t}$ \\
\hline Constant & $4.73(208.3)^{* * *}$ & $4.70(219.7)^{* * *}$ & $5.05(221.7)^{* * *}$ & $5.02(236.1)^{* * *}$ \\
\hline Time & $0.006(16.77)^{* * *}$ & $0.006(18.12)^{* * *}$ & $0.006(16.03)^{* * *}$ & $0.006(17.80)^{* * *}$ \\
\hline F- cal. & $281.141 * * *$ & $328.18 * * *$ & $257.03 * * *$ & $316.90^{* * *}$ \\
\hline R-square & 0.715 & 0.746 & 0.696 & 0.739 \\
\hline Exponential GR (\%) & 0.6 & 0.6 & 0.6 & 0.6 \\
\hline \multicolumn{5}{|c|}{ Nature of Growth Rate } \\
\hline Constant & $4.69(136.7)^{* * *}$ & $4.69(144.0)^{* * *}$ & $4.97(150.4)^{* * *}$ & $4.98(155.8)^{* * *}$ \\
\hline Time $\left(b_{1}\right)$ & $0.008(5.47)^{* * *}$ & $0.006(5.02)^{* * *}$ & $0.009(7.46)^{* * *}$ & $0.008(6.16)^{* * *}$ \\
\hline Time $\left(b_{2}\right)$ & $-1.55 \mathrm{e}-05(-1.34)$ & $-6.19 \mathrm{e}-06(-0.56)$ & $-3.80 \mathrm{e}-05(-3.51)^{* * *}$ & $-1.91 \mathrm{e}-05(-1.77)^{*}$ \\
\hline F- cal. & 142.45 & 163.24 & $146.47 * * *$ & $163.01 * * *$ \\
\hline R-square & 0.719 & 0.746 & 0.725 & 0.746 \\
\hline Inference & In significant GR & Insignificant GR & Sig. decelerated GR & Sig. decelerated GR \\
\hline
\end{tabular}

Note: Values in bracket represent t-values. The asterisks * and *** represent $10 \%$ and $1 \%$ significance levels respectively. Source: Own processing

Table 2: Exponential trend analysis of monthly average prices of local and foreign rice in rural and urban markets in Akwa Ibom State.

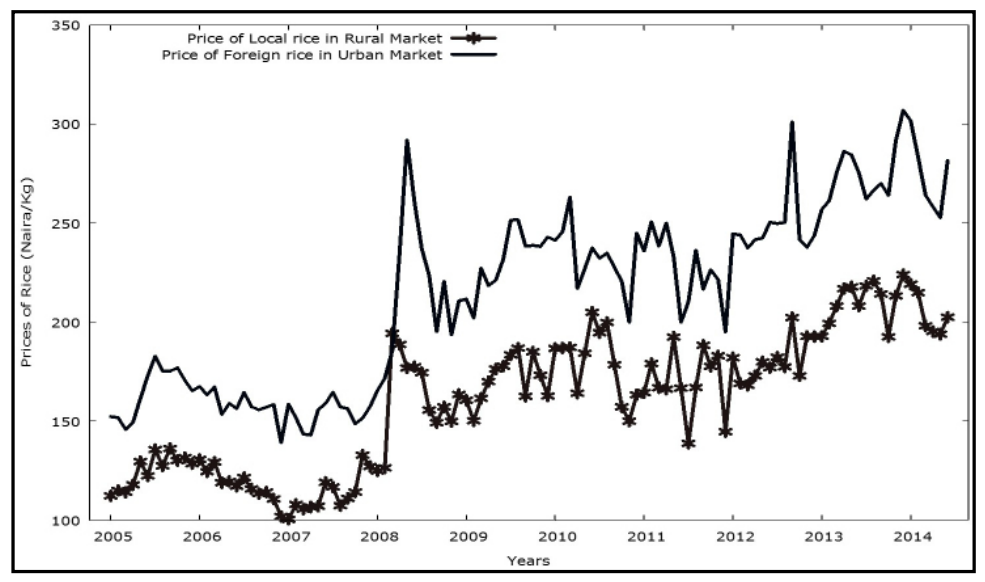

Source: Own processing

Figure 1: Trends in prices of local rice in urban market and foreign rice in urban market in Akwa Ibom State.

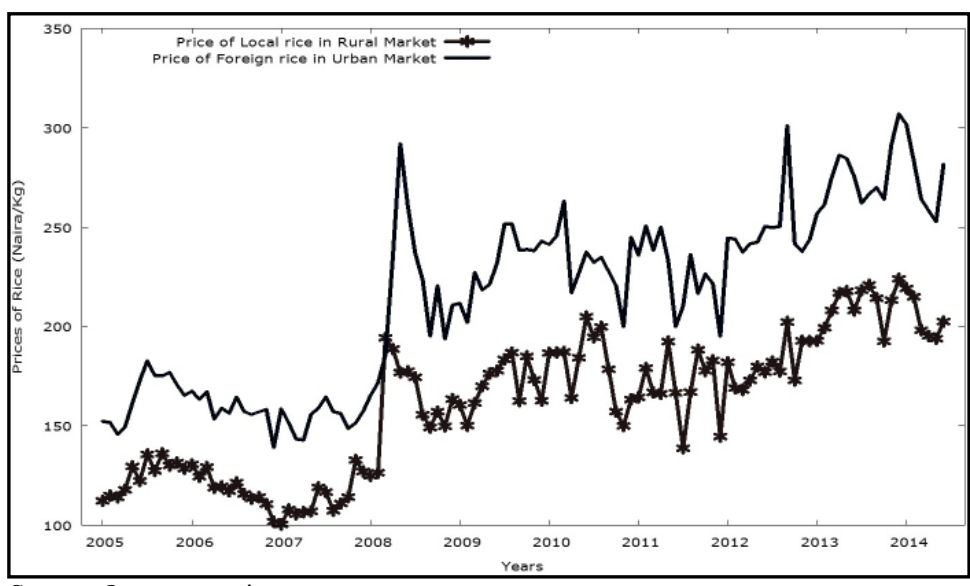

Source: Own processing

Figure 1: Trends in prices of local rice in urban market and foreign rice in rural market in Akwa Ibom State. 
correlation coefficients were estimated. The result is presented in Table 4. The result indicates that, the mean price of local rice in the rural market was significantly different from the mean price of foreign rice in the urban market. In the similar manner, the mean price of local rice in the urban market was significantly different from the mean price of foreign rice in the rural market. Within the same market, mean prices of foreign and local rice were also significantly different. This result further substantiates the possibility of high degree of competitiveness and substitutability of local rice for foreign rice. Fundamentally, this result suggests the presence of a strong market competition potential between the local and foreign rice market in the state. However, there is also an evidence of significant positive and linear relationship among price paired. This implies that, factors that affect rural price of both foreign and local rice are relatively similar to those in urban market.

\begin{tabular}{|c|c|c|}
\hline $\begin{array}{c}\text { Paired price } \\
\text { sample }\end{array}$ & $\begin{array}{c}\text { Paired t-test } \\
\text { (2-tailed) }\end{array}$ & $\begin{array}{c}\text { Paired sample } \\
\text { correlation }\end{array}$ \\
\hline $\boldsymbol{L}_{u t}-\boldsymbol{L}_{r t}$ & $3.754^{* * *}$ & $0.968^{* * *}$ \\
\hline $\boldsymbol{F}_{r t}-\boldsymbol{L}_{r t}$ & $34.294^{* * *}$ & $0.932^{* * *}$ \\
\hline $\boldsymbol{F}_{r t}-\boldsymbol{L}_{u t}$ & $-36.083^{* * *}$ & $0.934^{* * *}$ \\
\hline $\boldsymbol{F}_{u t}-\boldsymbol{L}_{r t}$ & $-32.561^{* * *}$ & $0.938^{* * *}$ \\
\hline $\boldsymbol{F}_{u t}-\boldsymbol{L}_{u t}$ & $36.759^{* * *}$ & $0.953^{* * *}$ \\
\hline $\boldsymbol{F}_{u t}-\boldsymbol{F}_{r t}$ & $-4.358^{* * *}$ & $0.969^{* * *}$ \\
\hline
\end{tabular}

Note: Computed by authors, and variables as defined in equation 2. Null hypothesis of no significance difference in means of paired prices were rejected at $1 \%$ probability level. Asterisk means significant at 1\% significant level.

Source: Own processing

Table 3: Paired t-test and correlation of price variables used in the analysis.

\section{Augmented Dicker Fuller Unit Root Test result}

The stationary status of series was examined by the unit root tests. One of the most commonly used unit root tests is the Augmented DickerFuller test (Dickey and Fuller, 1979). The ADF test was conducted by including constant on one part and constant and trend on the other part. Only $1 \%$ critical value (or $99 \%$ of repeatability) was used to determine the unit root of variables. For instance, a price series is stationary if its mean and variance are constant over time under consideration. The summary of the result of the ADF root tests is presented in Table 4. The result shows that, all price variables were non-stationary at levels but stationary at first difference for ADF equation that contains constant. However, mixed result was obtainable for ADF equation that contains both constant and trend. To avoid incidence of spurious regression, the study was built on the assumption that price variables were non-stationary at level but stationary at first difference.

The result implies that, the specified price variables equation should be tested for the existence of co-integration among variables (Johansen, 1988; Johansen and Juselius, 1990). This result, however, conforms to the findings of Chirwa (2000); Acquah and Owusu (2012) and Akpan, Inimfon and Udoka (2014). They opine that, most agricultural commodity prices in the Sub-Saharan Africa are integrated at the first order.

\section{Bilateral Granger causality test between prices of local and foreign rice}

The long run causality relationship between the rural and urban prices of local and foreign rice was investigated in Akwa Ibom State. The result of the analysis is presented in Table 5. The result

\begin{tabular}{|l|c|c|c|c|c|c|}
\hline \multirow{2}{*}{$\begin{array}{l}\text { Logged } \\
\text { variables }\end{array}$} & \multicolumn{5}{|c|}{ Augmented Dicker Fuller Test for unit root } \\
\cline { 2 - 7 } & \multicolumn{3}{|c|}{ With constant } & \multicolumn{3}{c|}{ Constant and trend } \\
\cline { 2 - 7 } & Level & $1^{\text {st }}$ diff. & OT & Level & $1^{\text {st }}$ diff. & OT \\
\hline $\boldsymbol{L n} \boldsymbol{L}_{\boldsymbol{r t}}$ & -2.209 & $-13.58^{* *}$ & $1(1)$ & -4.035 & $-13.52^{* *}$ & $1(1)$ \\
\hline $\boldsymbol{L n} \boldsymbol{F}_{\boldsymbol{u t}}$ & -1.951 & $-12.28^{* *}$ & $1(1)$ & -3.839 & $-12.22^{* *}$ & $1(1)$ \\
\hline $\boldsymbol{L n} \boldsymbol{L}_{u t}$ & -2.232 & $-14.70^{* *}$ & $1(1)$ & $-4.205^{* *}$ & - & $1(0)$ \\
\hline $\boldsymbol{L n} \boldsymbol{F}_{\boldsymbol{r t}}$ & -2.243 & $-13.84^{* *}$ & $1(1)$ & $-4.064^{* *}$ & - & $1(0)$ \\
\hline $\mathbf{1 \%}$ & -3.489 & -3.49 & & -4.04 & -4.04 & \\
\hline
\end{tabular}

Note: OT means order of integration. Critical value $(\mathrm{CV})$ is defined at $1 \%$ significant level and asterisks $* *$ represent $1 \%$ significance level. Variables are as defined in equation 2.

Source: Own processing

Table 4: Result of the unit root test for price variables used in the analysis. 


\begin{tabular}{|l|c|c|c|c|c|}
\hline Hypotheses & Lag & Sample size & F-Statistic & Prob. & Decision \\
\hline $\boldsymbol{L} \boldsymbol{n} \boldsymbol{L}_{\boldsymbol{r t}}$ does not Granger cause $\boldsymbol{L} \boldsymbol{n} \boldsymbol{F}_{\boldsymbol{u t}}$ & 1 & 113 & 12.568 & $0.000^{* * *}$ & Rejected \\
\hline $\boldsymbol{L} \boldsymbol{n} \boldsymbol{F}_{\boldsymbol{u} \boldsymbol{t}}$ does not Granger cause $\boldsymbol{L} \boldsymbol{n} \boldsymbol{L}_{\boldsymbol{r} t}$ & 1 & 113 & 7.189 & $0.009 * *$ & Rejected \\
\hline $\boldsymbol{L} \boldsymbol{n} \boldsymbol{L}_{\boldsymbol{u} \boldsymbol{t}}$ does not Granger cause $\mathbf{L n F}$ & 1 & 113 & 9.615 & $0.003 * * *$ & Rejected \\
\hline $\boldsymbol{L} \boldsymbol{n} \boldsymbol{F}_{\boldsymbol{r t}}$ does not Granger cause $\boldsymbol{L} \boldsymbol{n} \boldsymbol{L}_{\boldsymbol{u t}}$ & 1 & 113 & 11.380 & $0.001 * * *$ & Rejected \\
\hline
\end{tabular}

Note: Variables are as defined in equation 2.

Source: Own processing

Table 5: A cross product Granger Causality estimates.

suggests that there is an evidence of bi-directional Granger causality between the rural price of local rice and urban price of foreign rice and vice versa.

This means that, the urban price of local rice significantly impacted on the rural price of foreign rice and vice versa. In a similar way, the previous price of local rice in urban market significantly determined the current price of foreign rice in the rural market and vice versa. The presence of bi-directional Granger Causality relationships between the price of local and foreign rice in the rural and urban markets indicates that, both product prices have strong co-movements. This means that, local rice is a good substitute for foreign rice and vice versa. It is inferred that, price of local rice is endogenously determined by price of foreign rice in both markets and vice versa. This result suggests possible co-integration between the local and foreign rice market in the study area. The symmetric price movement between these two markets is an indication of the presence of strong competition and substitutability of the two products.

\section{Co-integration model for the local and foreign} rice markets

The result of the Engle and Granger two-step technique of co-integration regression tests for the residuals (ECM) generated in the long run equations specified in equations 7 and 8 is presented in the lower portion of Table 6 and 7. The results show that at $1 \%$ probability level of significance, the $\mathrm{ADF}$ for the residuals is greater than the critical value (-4.05). Thus the Engle-Granger co-integration test rejected the null hypothesis of no co-integration for the pair of price equations described in Table 7 and 8. Hence, there exist a stable long run equilibrium relationship between the local rice market and foreign rice market in the region.

\begin{tabular}{|l|c||l|c|}
\hline Variable & $\boldsymbol{L n}_{r t}=\boldsymbol{f}\left(\boldsymbol{L n F}_{u}\right)$ & Variable & $\boldsymbol{L n F}_{u t}=\boldsymbol{f}\left(\boldsymbol{L n} \boldsymbol{L}_{r \boldsymbol{}} \boldsymbol{)}\right.$ \\
\hline Constant & $-0.129(-0.783)$ & Constant & $0.659(4.434)^{* * *}$ \\
\hline $\boldsymbol{L n} \boldsymbol{P}_{2 t}$ & $0.9699(31.59)^{* * *}$ & $\boldsymbol{L n} \boldsymbol{P}_{4 t}$ & $0.927(31.59)^{* * *}$ \\
\hline F-cal & $997.99 * * *$ & F-cal & $997.99^{* * *}$ \\
\hline $\mathbf{R}^{2}$ & 0.899 & $\mathbf{R}^{2}$ & 0.899 \\
\hline DW- test & 1.376 & DW- test & 1.351 \\
\hline \multicolumn{4}{|c|}{ ADF test for errors from above equations } \\
\hline ECM $_{t}$ & $-7.642^{* * *}$ & & $-7.680^{* * *}$ \\
\hline
\end{tabular}

Note: the equation for the ADF test include constant and trend. Critical value at $1 \%=-4.05$, Values in bracket represent $t$-values. The asterisk *** represents $1 \%$ significance level. Variables are as defined in equation 2.

Source: Own processing

Table 6: Long run relationships between prices of local and foreign rice.

The Johansen co-integration test was also used to verify the Engle Granger two-step methodology. The Johansen co-integration test result showed that, the trace and maximum eigenvalues were significant at first rank level. The result is presented in Table 9 and Table 10. The two results are similar, the calculated trace test and maximum eigenvalue test statistics are greater than the critical values at $5 \%$ probability level. These further confirm the presence of at least one co-integration relationship between the specified price variables. The upper part of Table 6 and Table 7 present the long run estimates of the respective pair equation.

\begin{tabular}{|l|c||l|c|}
\hline Variable & $\boldsymbol{L n L}_{u t}=\boldsymbol{f}\left(\boldsymbol{L n} \boldsymbol{F}_{r t}\right)$ & Variable & $\boldsymbol{L n}_{r t}=\boldsymbol{f}\left(\boldsymbol{L n}_{u t}\right)$ \\
\hline Constant & $-0.168(-0.987)$ & Constant & $0.727(4.79)$ \\
\hline $\boldsymbol{L n} \boldsymbol{P}_{2 t}$ & $0.969(30.63)^{* * *}$ & $\boldsymbol{L n P}_{4 t}$ & $0.921(30.63)^{* * *}$ \\
\hline F-cal & $938.45^{* * *}$ & F-cal & $938.45^{* * *}$ \\
\hline $\mathbf{R}^{2}$ & 0.893 & $\mathbf{R}^{2}$ & 0.893 \\
\hline DW- test & 1.446 & DW- test & 1.462 \\
\hline \multicolumn{4}{|c|}{ ADF test for errors from above equations } \\
\hline ECM $_{t}$ & $-8.233^{* * *}$ & & $-7.979^{* * *}$ \\
\hline
\end{tabular}

Note: The equation for the ADF test include constant and trend. Critical value at $1 \%=-4.05$, Values in bracket represent $t$-values. The asterisk $* * *$ represents $1 \%$ significance level. Variables are as defined in equation 2.

Source: Own processing

Table 7: Long run Relationships between prices of local and foreign rice. 
The Johansen co-integration test results further reaffirmed the presence of potential stable long run relationship between price of local rice and price of foreign rice in rural and urban market of the state.

\section{Error Correction Model for the local and foreign} rice market

The presence of co-integration between the specified variables demanded the specification of the Error Correction Model. Table 10 contains estimates of the error correction model (ECM) generated for the rural price equations of local and foreign rice market; while Table 11 contains estimates of ECM generated for the urban price equations. Coefficient of the error correction term in each equation is negative and statistically significant at $1 \%$ probability level. The result established the existence of a long-run equilibrium relationship between the price of local and foreign rice in the rural markets. This means that, there is a long run sustainable and stable substitution or competition between the local and foreign rice in the region. The result further implies that, the rural prices of local and foreign rice are sensitive to departure from their equilibrium states or levels in the previous periods. For the rural price equations, the slope coefficient of the error correction term $(-0.667$ for the local rice) and (-0.581 for foreign rice) represent the speed of adjustment and also is consistent with the hypothesis of convergence towards the long-run equilibrium once the rural price equation is disturbed. This means that, it will take the rural price of local rice about 6 weeks and rural price of foreign rice about 6 weeks 6 days to adjust fully to stable equilibrium position in the long run due to disturbances in the marketing system. Hence, it seems the local rice market leads the foreign rice market in the rural area of the state. This means that substitution and competitiveness favours the local rice market in the rural areas. This satisfies a priori expectation given the poverty rate in the rural areas of the country. It is likely that most rural dwellers could not afford the foreign rice due to high price.

\begin{tabular}{|c|c|c|c|c|c|}
\hline Rank & Eigen value & Trace test & p-value & Lmax. test & p-value \\
\hline 0 & 0.3560 & 53.126 & {$[0.0000]$} & 49.730 & {$[0.0000]$} \\
\hline 1 & 0.0296 & 3.395 & {$[0.0654]$} & 3.395 & {$[0.0654]$} \\
\hline
\end{tabular}

Note: Unrestricted constant; Log-likelihood $=606.57$ (including constant term: 285.89 ). Lag length $=1$. Source: Own processing

Table 8: Results of Johansen cointegration test (unrestricted constant) for $\operatorname{Ln} L_{r t}=f\left(\operatorname{LnF}{ }_{u t}\right)$.

\begin{tabular}{|c|c|c|c|c|c|}
\hline Rank & Eigen value & Trace test & p-value & Lmax. test & p-value \\
\hline 0 & 0.3753 & 57.039 & {$[0.0000]$} & 53.155 & {$[0.0000]$} \\
\hline 1 & 0.0338 & 3.883 & {$[0.0488]$} & 3.883 & {$[0.0488]$} \\
\hline
\end{tabular}

Note: Unrestricted constant; $=596.843$ (including constant term: 276.163 ) Lag length $=1$. Source: Own processing

Table 9: Results of Johansen Cointegration Test (unrestricted constant) for $\operatorname{Ln} P_{3 t}=f\left(\operatorname{Ln} P_{41}\right)$.

\begin{tabular}{|l|c|c|}
\hline Variable & Urban price of local rice & Urban price of foreign rice \\
\hline Constant & $0.002(0.263)$ & $0.002(0.349)$ \\
\hline$\Delta$ LnSelf-Lag & $0.0874(0.854)$ & $-0.084(-0.847)$ \\
\hline$\Delta$ LnRural price (level) & $\mathbf{0 . 7 0 6}(\mathbf{8 . 0 5 8})^{* * *}$ & $\mathbf{0 . 6 1 9}(\mathbf{7 . 7 3 2})^{* * *}$ \\
\hline$\Delta$ LnRura price (lag 1) & $-0.1307(-1.267)$ & $0.011(0.116)$ \\
\hline $\boldsymbol{E C M}_{t-1}$ & $\mathbf{- 0 . 6 6 7 ( - 5 . 7 3 3 ) ^ { * * * }}$ & $\mathbf{- 0 . 5 8 1}(\mathbf{- 5 . 1 9 4})^{* * *}$ \\
\hline $\mathbf{R}^{2}$ & 0.447 & 0.454 \\
\hline F-cal & $21.629^{* * *}$ & $22.269^{* * *}$ \\
\hline DW & 1.978 & 1.976 \\
\hline
\end{tabular}

Note: Values in bracket represent t-values. Asterisk * and $* * *$ represent $10 \%$ and $1 \%$ significance level respectively. Variables are as defined in equation 2.

Source: Own processing

Table 10: ECM estimates for the rural Price of Local and Foreign rice in Akwa Ibom State, Southern Nigeria. 


\begin{tabular}{|l|c|c|}
\hline Variable & Urban price of local rice & Urban price of foreign rice \\
\hline Constant & $0.003(0.543)$ & $0.003(0.575)$ \\
\hline$\Delta$ LnSelf-Lag & $-0.159(-1.707)^{*}$ & $0.124(1.376)$ \\
\hline$\Delta$ LnRural price (level) & $\mathbf{0 . 5 6 1}(\mathbf{7 . 7 1 0})^{* * *}$ & $\mathbf{0 . 5 1 0}(\mathbf{7 . 8 6 0})^{* * *}$ \\
\hline$\Delta$ LnRura price (lag 1) & $0.049(0.524)$ & $-0.210(-2.463)^{* *}$ \\
\hline $\boldsymbol{E C M}_{\boldsymbol{t}-\mathbf{1}}$ & $\mathbf{- 0 . 5 2 0}(\mathbf{- 4 . 9 7 1 )})^{* * *}$ & $\mathbf{- 0 . 6 8 1}(\mathbf{7 . 0 5 5})^{* * *}$ \\
\hline $\mathbf{R}^{2}$ & 0.473 & 0.486 \\
\hline F-cal & $24.010^{* * *}$ & $25.321^{* * *}$ \\
\hline DW & 2.093 & 1.912 \\
\hline
\end{tabular}

Note: Values in bracket represent t-values. Asterisk * and *** represent $10 \%$ and $1 \%$ significance level respectively. Variables are as defined in equation 2.

Source: Own processing

Table 10: ECM estimates for the rural Price of Local and Foreign rice in Akwa Ibom State, Southern Nigeria.

ECM for the urban price of local and foreign rice market

For the urban price of local and foreign rice, the respective slope coefficient of the error correction term is $(-0.520)$ and $(-0.681)$, and are statistically significant at $1 \%$ level. This implies that, the rural prices will always react to bring stability in the urban prices whenever there is significant variation between them. About 52.20\% and $68.10 \%$ of the urban price adjustment takes place within every month due to exogenous shock. This means that, it will take about 7 weeks 5 days and 5 weeks 5 days for the urban price of local rice and foreign rice respectively to adjust fully to a stable equilibrium position in the long run. By implication, movements in urban prices of local and foreign rice are significantly detected by its respective rural prices. The adjustment is faster in foreign rice than the local rice. This result implies that, the foreign rice market is more active and possibly dominates the local rice market in urban areas of the state. This result fit into the apriori outcome; given the income level, awareness, preference, education and other social attributes of urban dwellers in Nigeria. Predictably, urban dwellers preferred high quality foreign rice to locally produce one. This speed up the activities in the foreign rice market compared to local rice market. The diagnostic test for the urban price equation revealed the $\mathrm{R} 2$ value of 0.473 and 0.486 for the local and foreign rice market respectively. The F-statistic of 24.01 and 25.32 are significant at $1 \%$ probability level respectively, indicating that, both equations have goodness of fit.

\section{Discussion of the long run and short run models}

The empirical results presented above, revealed that, the long run model for the rural and urban prices of local and foreign rice almost converged to the postulate of the law of one price. The long run market integration coefficient for each of the commodity was approximately unity. This confirms the existence of the long run stable price integration in each of the specified equation. This means that, there is evidence of stability in price movement between the local and foreign rice in the long run in both rural and urban market. In other words, the substitution or the competition between the local and foreign rice showed sign of stability in the long run in both rural and urban markets in Akwa Ibom State. Hence, price change in the local rice in the rural market is instantaneously transmitted into price change in foreign rice in urban market and vice versa. This result shows the high degree of competiveness and substitutability of local rice for foreign rice especially in the urban market. It means that, in the long run the price of foreign rice determined the price of local rice and vice versa. The constant terms in the four long run equations give pictures of transfer cost or the extent of price differential between the dependent and independent market price. The result further revealed insignificant influence of transfer costs in the marketing process of local and foreign rice in the state. This perhaps suggests high efficiency in information transmission between the rural and urban markets and improvement in the marketing infrastructures in the state. In the ECM models; the short run market integration coefficients are significantly different from unity for both rural and urban markets. These results imply that, in the short run, price change in local rice does not instantaneously lead to price change in foreign rice and vice versa in both markets. This means that, in the short run the level of competiveness and substitutability 
of local rice for foreign rice is low. The same is also applied for the reverse situation.

\section{Conclusion}

The study employed statistical and econometric techniques to analyze the horizontal price transmission between the local and foreign rice market in the rural and urban markets in Akwa Ibom State, Southern Nigeria. The results showed that, prices of local and foreign rice in the rural and urban markets have positive relationship with time and constant exponential growth rate of $0.60 \%$ in the period under consideration. The graphical trend analysis showed that, both rural and urban prices co-moved with noticeable deviations within the period under consideration. The result suggested the prevalence of strong market competitiveness and substitutability between the local and foreign rice commodity in Akwa Ibom State. Price variability was higher in local rice compared to foreign rice. It was discovered that, the price of local rice was cheaper in urban market compared to the rural market. This clearly showed that, consumers in the region preferred foreign rice to local rice. Also, the Pearson correlation coefficient revealed that, the price of local rice has a strong positive linear symmetric relationship with the price of foreign rice in the state. The result connotes the existence of efficient and symmetric market information flows between the local and foreign rice markets in the region. The pair wise t-test result revealed a significant difference between the mean price of local and foreign rice in both markets. The Granger causality test revealed bidirectional relationship between the price of local and foreign rice in both rural and urban markets in the region. This also suggested that, the price transmission mechanism between the local and foreign rice markets is efficient; and a high tendency for market integration as well as competitiveness and substitutability. The results of the co-integration test revealed the presence of the cross price co-integration between the local and foreign rice market in the region. The coefficients of the long run market integration in the co-integration equations for local and foreign rice market almost converged to unity; which connotes instantaneous and stable long run price relationship between the two markets. The results of the short run model also confirmed the existence of the short run co movement between the local and foreign rice markets in the study area. In addition, it shows that, the rural price of local rice and urban price of foreign rice adjusted faster than their respective counterpart. However, the result revealed that, the substitution and the competition between the local and foreign rice market is stronger in the long run than the short run.

Using the price transmission analysis, this study has confirmed that, there is a strong short and long run relationship between the price of the local rice and foreign rice in the study area. It is assumed that, the strong price relationship arose from the strong competition or substitutability in the two categories of rice. Hence, it is established in this study that, there is a strong price competition and endogenity characteristic between the local and foreign rice markets in the region. This means that, the local rice market has potentials to compete and substitute for the foreign rice market in Nigeria. It is an established fact that, the local rice market is less competitive in terms of value addition, quantity and quality compared to the foreign rice market; comparing the price trend over time, our result revealed that the local rice market has a lot of potentials to compete efficiently with foreign counterpart in the region.

Based on the finding, it is recommended that, short and long term price policies should be used to intervene in the rice sub sector in the state. Policies aimed at boosting local production of rice should be encouraged. Value additions in locally produced rice should be included in any policy framework meant to boost rice production in the region.

\section{Corresponding author:}

Sunday Brownson Akpan

Department of Agricultural Economics and Extension, Akwa Ibom State University

Mkpat Enin, Akwa Ibom State, Nigeria.

Phone: +234-08036728337; E-mail: brownsonakpan10@gmail.com 


\section{References}

[1] Abdulai, A. (2000) "Spatial price transmission and asymmetry in the Ghanaian maize market” Journal of Development Economics. Vol. 63, pp. 327-349. ISSN 0304-3878. DOI: 10.1016/S03043878(00)00115-2.

[2] Acquah, H. D. and Owusu, O. (2012) „Spatial market integration and price transmission of selected plantain markets in Ghana“, Journal of Sustainable Development in Africa. Vol. 14, No. 5, pp. 208-217. ISSN 1520-5509.

[3] Akintunde, O. K., Akinremi, T. B., and Nwauwa, L. O. (2012) „Food Grain Marketing in Osun State, Nigeria: a study of long-run price integration", Continental J. of Agricultural Economics, Vol. 6, No. 1, pp. 1 - 9. ISSN 2141 - 4130. DOI: 10.5707/cjae.2012.6.1.1.9.

[4] Akpan, S. B., and Aya, A. E. (2009) „Variance in Consumer Prices of selected Food items among Markets in Cross River State“, Global Journal of Social Sciences. Vol. 8, No., pp. 59-62. ISSN $1596-6216$.

[5] Akpan, S. B., Inimfon V. P., Samuel J. U. (2014) „Analysis of Monthly Price Transmission of Local and Foreign Rice in Rural and Urban Markets in Akwa Ibom State, Nigeria (2005 to 2013), International Journal of Agriculture and Forestry. Vol. 4, No. 1, pp. 6-18. ISSN 2165-882X; E-ISSN 2165-8846. DOI: 10.5923/j.ijaf.20140401.02.

[6] Akpokodje, G., Frederic, L., and Olaf, E. (2001) "Nigeria's Rice Economy: State of the Art", Paper presented at the workshop on "The Nigerian Rice Economy in a Competitive World: Constraints, Opportunities and Strategic Choices", Nigerian Institute of Social and Economic Research (NISER), Ibadan, Nigeria, 8-9 th $^{\text {November, }} 2001$.

[7] Awe, O. (2006) „Ban on Rice Importation Depresses Global Trade“, Punch Newspaper, 2006, May 20. [Online] Available: http://www.punchng.com/ [Accessed: Jan 20, 2015].

[8] Baffes J. (1991) „Some Further Evidence on the Law of One Price: The Law of One Price Still Holds.“ American Journal of Agricultural Economics. Vol. 73, No. 4, pp. 1264-1273. E-ISSN 1467-8276, ISSN 0002-9092, DOI: 10.2307/1242454.

[9] Baffes J., Ajwad, M. I. (2001) „Identifying price linkages: a review of the literature and an application to the world market of cotton“, Applied Economics. Vol. 33, No. 15, pp. 1927-1941. ISSN 0003-6846, E-ISSN 1466-4283, DOI: 10.1080/00036840010023788.

[10] Bakucs, L. Z., Ferto, I. and Szabo, G. G. (2007) „Price transmission in the Hungarian vegetable sector“, Studies in Agricultural Economics, No. 106, pp. 23 - 40. ISSN 1418-2106.

[11] Barrett, C. B. and Li, J. R. (2002) "Distinguishing between Equilibrium and integration in spatial price analysis", American Journal of Agricultural Economics, Vol. 84, No. 2, pp. 292 - 307. E-ISSN 1467-8276, ISSN 0002-9092., DOI:10.1111/1467-8276.00298.

[12] Ben-Kaabia, M. and Gil, J. M. (2007) „Asymmetric price transmission in the Spanish lamp sector“, European Review of Agricultural Economics. Vol. 34, No. 1, pp. 53 - 80. E-ISSN 1464-3618, ISSN 0165-1587, DOI: 10.1093/erae/jbm009.

[13] Chirwa, E. W. (2000) „Liberalization of Food Marketing and Market Integration in Malawi“, Final Report of an AERC Sponsored Research Work Presented at the Biannual Economic Research Workshop, Nairobi, Kenya.

[14] Daramola, B. (2005) „Government Policies and Competitiveness of Nigerian Rice Economy“. A paper presented at the 'Workshop on Rice Policy \& Food Security in Sub-Saharan Africa'organized by WARDA, Cotonou, Republic of Benin, November 7- 9, 2005.

[15] Dawson, P. J. and P. K. Dey (2002) „Testing for the Law of One Price: Rice Market Integration in Bangladesh“, Journal of International Development, Vol. 14, No. 4, pp. 473-484. E-ISSN 1099-1328, DOI: 10.1002/jid.888. 
[16] Debaniyu, I. F. (2013) „Price integration of cowpea retail markets in Niger state, Nigeria“, Academic Research International. Vol., 4, No. 3, pp. 264 - 277. ISSN 2223-9553.

[17] Dickey, D. A. and Fuller, W. A. (1979) "Distribution of the estimators for autoregressive time series with a unit root", Journal of the American Statistical Association, Vol. 74, pp. 427-431. ISSN 0162-1459, E-ISSN 1537-274X. DOI:10.1080/01621459.1979.10482531.

[18] Enders, W. and Silkos, P. (1999) „Cointegration and threshold adjustment The University of Alabama Economics“, Finance and Legal Studies Working Paper Series, No. 01-03-02.

[19] Erenstein, O., Lancon, F., Osinname, O. and Kebbeh, M. (2004) „Operationizing the Strategic Framework for rice Sector revitalization in Nigeria“, The Nigerian rice economy in a competitive world; Constraints, opportunities and Strategies Choices, projects Report, p. 38.

[20] Esfahani, F. Z. (2006) „Testing the Law of One Price in the Chinese Wholesale Food Markets“, Journal of Agribusiness. Vol. 22, No. 4, pp. 569-589. ISSN 152- 6297. DOI: 10.1002/agr.20104.

[21] Esposti, R. and Listorti, G. (2011) „Agricultural price transmission across space and commodities during price bubbles“, paper presented at the EAAE 2011 Congress, Change and Uncertainty Challenges for Agriculture, Food and Natural Resources, August to September 2011, Zurich.

[22] Famine Early Warning Systems Network (FEWSNET) (2008) Nigeria Food Security Outlook, March to September 2008.

[23] Faminow, M. D., and Benson. B. L. (1990) "Integration of spatial markets", American Journal of Agricultural Economics. Vol. 72, No. 1, pp. 49-62. E-ISSN 1467-8276, ISSN 0002-9092. DOI: $10.2307 / 1243144$

[24] Ferrucci, G., Jimenez-Rodríguez, R., Onorante, L. (2012) „Food Price Pass-through in the Euro Area: Non-linearities and the Role of the Common Agricultural Policy“, International Journal of Central Banking. Vol. 8, No. 1, pp. 179-217. ISSN 1815-4654.

[25] Forooz Jezghani, F., Moghaddasi, R., Yazdani F. and Mohamadinejad A. (2013) „Spatial Price Transmission: A Study of Rice Markets in Iran“, World Applied Sciences Journal. Vol. 21, No. 4, pp. 646-650. ISSN 1818-4952; E-ISSN 1991-6426. DOI: 10.5829/idosi.wasj.2013.21.4.1725.

[26] Ghoshray, A. (2011) „Underlying trends and international price transmission of agricultural commodities“, Asian Development Bank economics working paper series; Series No. 257.

[27] Goletti, F. and Babu, S. (1994) „Market liberalization and market integration of maize markets in Malawi“, Agricultural Economics, Vol. 11, p. 311-324. E-ISSN 1574-0862.

[28] Gonzalez-Rivera, G. and Helfand, S. M. (2001) „The Extent, Pattern, and Degree of Market Integration: A Multivariate Approach for the Brazilian Rice Market". American Journal of Economics. Vol. 83, No. 3, pp. 576-592. E-ISSN 1467-8276, ISSN 0002-9092.

[29] Gonzalez-Rivera, G., and Helfand, S. (2001),,The Extent, Pattern and Degree of Market Integration: A Multivariate Approach for the Brazilian Rice Market", American Journal of Agriculture Economics, Vol. 83, No. 3, p. 576-592. E-ISSN 1467-8276, ISSN 0002-9092. DOI: $10.1111 / 0002-9092.00179$.

[30] Goodwin, B. K., and Schroeder, T. C. (1991) "Cointegration tests and spatial price linkages in regional cattle markets", American Journal of Agricultural Economics, Vol. 73, No. 2, p. 452-464. E- ISSN 1467-8276, ISSN 0002-9092, DOI: 10.2307/1242730.

[31] Goodwin, B. K., Harper, D. C. (2000) „Price transmission, threshold behavior and asymmetric adjustment in the US pork sector", Journal of Agricultural and Applied Economics. Vol. 32, No. 3, pp. 543-553. ISSN 1074-0708, E-ISSN 2056-7405.

[32] Hassan, D. and Simioni, M. (2001) „Price linkage and transmission between shippers and retailers in the French fresh vegetable channel“", Institut National de la Recherche Agronomique, Toulouse - France. 
[33] Hossain, M. I. and Verbeke, W. (2010) „Evaluation of Rice Markets Integration in Bangladesh“. The Lahore Journal of Economics. Vol. 15, No. 2, pp. 77-96. ISSN 1811-5438.

[34] Hussain, B. (2010) „Testing the Law of One Price in Gram Markets of Pakistan“, MPRA Paper, No. 30708, [Online] Available: http://mpra.repec.org/ [Accessed May 4, 2011].

[35] Johansen, S. (1988) "Statistical analysis of co-integration vectors", Journal of Economic Dynamics and Control, Vol. 12, p. 231-254. ISSN 0165-1889.

[36] Johansen, S. and Juselius, K. (1990) "Maximum likelihood estimation and inference on cointegration with applications to the demand for money", Oxford Bulletin of Economics and Statistics, Vol. 52, pp. 169-210. E-ISSN 1468-0084. DOI: 10.1111/j.1468-0084.1990.mp52002003.x.

[37] Kehinde I. K. (1999) „Agronomy of upland and lowland rice in Nigeria“, paper presented at the special rice production project (SRPP) held at APMEU, Kaduna, 26-28 April, 1999.

[38] Listorti, G., and Esposti, R. (2012) „Horizontal Price Transmission in Agricultural Markets: Fundamental Concepts and Open Empirical Issues“, Bio-based and Applied Economics, Vol. 1, No. 1, p. 81-96. ISSN 2280-6180, E-ISSN 2280-6172. DOI: 10.13128/BAE-10769.

[39] Lloyd, T. A., McCorriston, S., Morgan, C. W., Zgovu, E. (2012) „The experience of food price inflation across the EU in TRANSFOP“, Working Paper No. 5, TRANSFOP project, EU $7^{\text {th }}$ Framework Programme, Grant Agreement No. KBBE-265601-4-TRANSFOP, [Online] http://www.transfop.eu/. [Accessed May 10, 2014].

[40] National Population Council (NPC) (2006) Nigeria 2006 Population Census. [Online] Available: http://www.population.gov.ng/ [Accessed April 15, 2015].

[41] Odozi, J. C., and Bolarin T. O. (2012) „Governance options for price instability: A review of the food grain commodity in Nigeria“, Journal of Development and Agricultural Economics, Vol. 4, No. 4, pp. 93-100. ISSN 2006-9774. DOI: 10.5897/JDAE12.016.

[42] Okoh, R. N and Egbon, P. C. (2005) „The Integration of Nigeria’s Rural and Urban Foodstuffs Markets“, AERC Research Paper 151, Africa Economic Research Consortium, Nairobi.

[43] Ravallion, M. (1986) „Testing market integration“, American Journal of Agricultural Economics, Vol. 68, No. 2, pp. 292-307. E- ISSN 1467-8276, ISSN 0002-9092. DOI: 10.2307/1241654.

[44] Rrezitis, A. N., and Dimitris, N. P. (2013) „Investigating the Price Transmission Mechanism of the Greek Fresh Tomato Market with a Markov switching Vector Error Correction Model“", Agricultural Economics Review; Vol. 14, No. 2, pp. 29-45. ISSN 1109-2580.

[45] Sephton, P. S. (2003) „Spatial market arbitrage and threshold cointegration“, American Journal of Agricultural Economics, Vol. 85, No. 4, p. 1041-46. E-ISSN 1467-8276, ISSN 0002-9092.

[46] Sexton, R. J., Kling, C. L. and Carman. H. F. (1991) "Market integration, efficiency of arbitrage, and imperfect competition: methodology and application to U.S. celery", American Journal of Agricultural Economics, Vol. 73, No. 3, p. 568-580. E- ISSN 1467-8276, ISSN 0002-9092.

[47] Suryaningrum, D. A., Wen, I. C. and Ratya, A. (2013) „Analysis on Spatial Integration of Thailand and Vietnam Rice Market in Indonesia“, Greener Journal of Business and anagement Studies, Vol. 3, No. 7, pp. 333-342. ISSN 2276-7827.

[48] Udoh, E. J., Mbossoh E. R., Udoh, E. S. and Akpan, S. B. (2013) „The structure of food demand in urban city of Nigeria: An application of a Linearized Almost Ideal Demand System (LA/AIDS)“, Journal of Development and Agricultural Economics, Vol. 5, No. 1, pp. 12-18. ISSN 2006-9774. DOI: $10.5897 /$ JDAE12.042.

[49] United States Department of Agriculture (2015), Foreign Agricultural Services (FAS), Washington Dc, USA, February 2015.

[50] Vavra, P., Goodwin, B. K.(2005),AAnalysis of price transmission along the food chain“, OECD Food, Agriculture and Fisheries Working Papers, No. 3. OECD Publishing. DOI: 10.1787/752335872456. 
[51] Worako, T. K., Schalkwyk, H. D. V., Alemu, Z. G. and Agrekon, G. A. (2008) „Producer Price and Price Transmission in a Deregulated Ethiopian Coffee Market", Agrekon, Vol. 47, No. 4. ISSN 0303-1853, E-ISSN 2078-0400.

[52] Zahid, S., A. Qayyum and Shahid, W. (2007) „Dynamics of Wheat Market Integration in Northern Punjab, Pakistan“, The Pakistan Development Review, Vol. 46, No. 4, pp. 817-830. ISSN 0030-9729. 